\title{
The American Civil Justice System: From Recommendations to Reform in the 21st Century
}

\author{
Rebecca Love Kourlis* \& Brittany K.T. Kauffman ${ }^{* *}$
}

\section{INTRODUCTION}

There is national momentum around reducing the costs and delays associated with civil litigation, in order to continue to provide and protect access to the courts and in hopes of ensuring the viability of trials. Although these themes have resonated throughout the history of the civil litigation system, recent efforts have demonstrated a renewed and serious commitment by judges and attorneys around the country to developing updated procedures designed to serve these two interrelated goals. From initial efforts to identify and define the problems that plague the system, to efforts to develop and implement solutions, the past six years have seen a surge in attention to these issues. With pilot projects underway across the country implementing and testing solutions, we have moved from recommendations to reform. Although the pilot projects are diverse in their solutions, there are common themes across the state and federal projects. These themes provide insight into broad changes that are on the horizon for the American civil justice system.

\section{IDENTIFYING THE PROBLEM AND DEFINING THE SOLUTION}

A brief history of recent efforts provides a backdrop to the current landscape of innovation that exists today.

A. 2007-2009: IAALS, the ACTL Task Force, and the Final Report

In 2007, IAALS, the Institute for the Advancement of the American Legal System, and the American College of Trial Lawyers Task Force on

Executive Director, IAALS, the Institute for the Advancement of the American Legal System, University of Denver. IAALS is a national, independent research center dedicated to continuous improvement of the process and culture of the civil justice system. Further information on IAALS's mission and work can be found at http://iaals.du.edu.

** Manager, Rule One Initiative, IAALS. 
Discovery and Civil Justice (ACTL Task Force or Task Force) ${ }^{1}$ formed a partnership to study costs and delay in America's civil justice system and, if applicable, to propose solutions. ${ }^{2}$ The goal of the project was first to determine if a problem really existed in the system and, if so, to define and examine it. As a starting point, IAALS surveyed the Fellows of the American College of Trial Lawyers (ACTL). ${ }^{3}$ One of the major themes to emerge from that survey was that "[a]lthough the civil justice system is not broken, it is in serious need of repair. In many jurisdictions, today's system takes too long and costs too much." 4 A second theme to emerge from the survey results was that the current rules structure "does not always lead to early identification of the contested issues to be litigated," and thus contributes to a lack of focus and disproportionate discovery. ${ }^{5}$ Finally, the survey amplified a plea that judges should take an early and active role in managing cases in general, as well as the scope of discovery in particular, to contain costs. ${ }^{6}$ The respondents indicated that much of this cost and delay stems from discovery, particularly electronic discovery, but they also noted that the causes are much deeper and broader than discovery alone. ${ }^{7}$ What is clear is that civil litigation-along with our world-has changed profoundly since the prevailing civil procedures were adopted in 1938, and corresponding change in the civil justice system is needed to maintain the objectives of

1. Although the Task Force initially focused on concerns primarily regarding discovery and was correspondingly titled the American College of Trial Lawyers Task Force on Discovery, the mandate of the project broadened to include other aspects of the civil justice system. For this reason, the name of the Task Force was subsequently revised to acknowledge that the identified problems were not confined to discovery.

2. See Am. Coll. of TRial LaWyers TASK Force on Discovery \& InSt. FOR ADVANCEMENT OF THE AM. LEgAL SYS., INTERIM REPORT (INCLUDING 2008 LiTIGATION SURVEY of the Fellows of the American College of Trial LaWYers) ON THE JoINT ProJect of the AMERICAN COLLEGE OF TRIAL LAWYERS TASK FORCE ON DISCOVERY AND THE INSTITUTE FOR THE ADVANCEMENT OF THE AMERICAN LEGAL SYSTEM 1 (2008), http://iaals.du.edu/images/wygwam/ documents/publications/Interim_Report_Final_for_web.pdf [hereinafter IAALS/ACTL TASK FORCE SURVEY].

3. Id. at 2 .

4. Am. Coll. of Trial LaWyers TASK ForCe ON Discovery \& INST. FOR THE

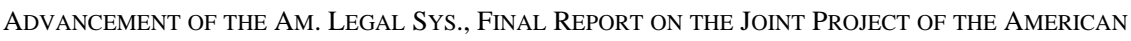
COLLEGE OF TRIAL LAWYERS TASK FORCE ON DISCOVERY AND THE INSTITUTE FOR THE ADVANCEMENT OF THE AMERICAN LEgAL SYSTEM 2 (rev. ed. 2009), http://iaals.du.edu/images/wygwam/documents/publications/ACTL-IAALS_Final_Report_rev_8-410.pdf [hereinafter FINAL REPORT].

5. Id.

6. See id.

7. See id. 
a "just, speedy, and inexpensive determination of every action"-the goals as set forth in Rule 1 of the Federal Rules of Civil Procedure.

Following the survey, and after a great deal of additional research, discussion, and deliberation, in 2009 IAALS and the Task Force published the Final Report with twenty-nine proposed Principles. ${ }^{8}$ The Principles contain broad ideas to improve the system, including changes in judicial management, pleading, discovery, experts, and education. IAALS and the Task Force intended that the Principles be tested and evaluated in pilot projects in courts around the country, and jointly developed a model set of Pilot Project Rules for this purpose. ${ }^{9}$

\section{B. 2009-2010: Additional Surveys by IAALS and the FJC}

A series of national surveys followed publication of the survey results and the Final Report. The Federal Judicial Center (FJC) administered two variations on the IAALS/ACTL Task Force survey in 2008, including a survey of the membership of the American Bar Association (ABA) Section of Litigation ${ }^{10}$ and the National Employment Lawyers Association (NELA). ${ }^{11}$ The FJC also surveyed attorneys in closed federal civil cases to, among other things, explore the costs of discovery, including electronic discovery. ${ }^{12}$ IAALS undertook two more surveys in an effort to gain additional perspectives: one survey of state and federal trial judges ${ }^{13}$ and another of chief legal officers and general counsel. ${ }^{14}$ The surveys all sought to gain additional insights regarding

8. See id. at 3-24.

9. Inst. FOR the AdVANCEMENT OF the Am. Legal Sys. \& AM. Coll. Of TRIAL LAWyers TASK FORCE ON DISCOVERY \& CiVIL JUSTICE, 21ST CENTURY CIVIL JUSTICE SYSTEM: A ROADMAP FOR REFORM: PILOT PROJECT RUles 1 (2009), http://iaals.du.edu/images/wygwam/documents /publications/Pilot_Project_Rules2009.pdf.

10. ABA Section of Litigation, ABA, ABA Section of Litigation MEmber Survey on CIVIL PRACTICE: FUlL REPORT (2009), http://americanbar.org/content/dam/aba/migrated/litiation /survey/docs/report_aba_report.authcheckdam.pdf.

11. Rebecca M. Hamburg \& Matthew C. Koski, Nat'L Emp't LaWyers Ass'N, Summary of Results of Federal Judicial Center Survey of NELA MEMBERS, Fall 2009 (2010), http://uscourts.gov/uscourts/RulesAndPolicies/rules/Duke\%20Materials/Library/NELA,\%20 Summary\%20of\%20Results\%20of\%20FJC\%20Survey\%20of\%20NELA\%20Members.pdf.

12. Emery G. Lee III \& Thomas E. Willging, Fed. Judicial Ctr., Federal Judicial Center National, Case-Based Civil Rules Survey: Preliminary Report to the Judicial CONFERENCE ADVISORY COMMITTEE ON CIVIL RULES 1 (2009), http://www.fjc.gov/public/pdf.nsf/ lookup/dissurv1.pdf/\$file/dissurv1.pdf.

13. Corina Gerety, Trial Bench Views: IAALS Report on Findings from a National Survey on Civil Procedure, 32 PACE L. REV. 301 (2012).

14. InSt. FOR THE AdVANCEMENT OF the AM. Legal Sys., Civil Litigation SuRVEy of

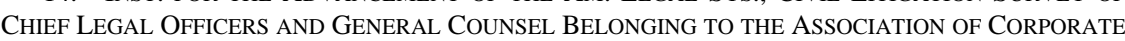


the challenges facing the civil justice system, and to determine areas of agreement and disagreement among the diverse respondent groups. IAALS also conducted multiple empirical studies of court procedures around the country to gain insights into what is working, and what is not, in various jurisdictions. These studies include a 2009 study of civil case processing in the federal district courts; ${ }^{15}$ a 2010 survey of the Arizona bench and bar on the Arizona Rules of Civil Procedure; ${ }^{16}$ a 2010 survey of the Oregon bench and bar on the Oregon Rules of Civil Procedure; ${ }^{17}$ and a 2010 study of civil case processing in Multnomah County, Oregon. ${ }^{18}$ More recently, IAALS has studied a simplified rule for smaller cases that has been in place in Colorado since $2004 .{ }^{19}$

\section{2010: The Duke Conference}

In May of 2010, the federal Civil Rules Advisory Committee convened a Conference on Civil Litigation at Duke University. The conference brought together rule makers, legal scholars, practitioners, judicial officers, professional associations, and researchers. Prior to the conference, participants submitted study results, papers, and proposals, which reflected the collective efforts around the country to analyze the current status of the civil justice system and propose solutions to problems. ${ }^{20}$ The general consensus was consistent with the results of the IAALS/ACTL Task Force survey-the current system, for certain kinds

COUNSEL (2010), http://iaals.du.edu/images/wygwam/documents/publications/Civil_Litigation_Sur vey2010.pdf.

15. InSt. FOR THE AdVANCEMENT OF THE Am. Legal Sys., CiVIL CASE PROCESSING IN THE FEDERAL District COURTS: A 21st CENTURY ANALYSIS (2009), http://iaals.du.edu/images/wy gwam/documents/publications/PACER_Final_1-21-09.pdf.

16. InSt. FOR THE ADVANCEMENT OF THE AM. LEgAL SYS., SURVEY OF THE ARIZONA BENCH \& BAR ON THE ARIZONA RULES OF CIVIL PROCEDURE (2010), http://iaals.du.edu/images /wygwam/documents/publications/Survey_Arizona_Bench_Bar2010.pdf.

17. InSt. FOR THE AdVANCEMENT OF THE AM. LEgAL SYS., SURVEY OF THE OREgON BENCH \& BAR ON THE OREgON RULES OF CIVIL PROCEDURE (2010), http://iaals.du.edu/images /wygwam/documents/publications/Survey_Oregon_Bench_Bar2010.pdf.

18. Inst. For the AdVANCEMENT OF the AM. Legal Sys., Civil CASE PROCESSING IN THE OREGON COURTS: AN ANALYSIS OF MultNOMAh COUNTY (2010), http://iaals.du.edu/images /wygwam/documents/publications/Civil_Case_Processing_Oregon_Courts2010.pdf.

19. CoRina D. GERETy \& LOgAn CORNETT, InST. FOR THE AdVANCEMENT OF THE AM. Legal Sys., Measuring Rule 16.1: Colorado's Simplified Civil Procedure ExPeriment (2012), http://iaals.du.edu/images/wygwam/documents/publications/Measuring_Rule_16-1.pdf.

20. For access to the scholarly papers, empirical research, and agenda materials from the conference, see 2010 Civil Litigation Conference, U.S. CTS., http://www.uscourts.gov/RulesAnd Policies/FederalRulemaking/Overview/DukeWebsiteMsg.aspx (last visited Feb. 15, 2013). 
of cases, is "often too costly" and cases take too long to complete. ${ }^{21}$ There was some divergence on the question of whether all cases-small and large-are victims of this phenomenon. ${ }^{22}$ While discovery was identified as a leading culprit, the materials also supported earlier and more extensive judicial case management. ${ }^{23}$

Following the conference, various groups of attorneys and judges in jurisdictions throughout the country began to develop pilot projects designed to address these issues. The Discovery Subcommittee of the Civil Rules Advisory Committee also began work on rules proposals to address preservation and sanctions issues. ${ }^{24}$ A Duke Conference Subcommittee was also formed to address many of the ideas raised at the conference, ${ }^{25}$ and this subcommittee is currently considering sketches of significant draft rule changes. ${ }^{26}$ Hence, the Duke Conference saw a sea change as attorneys, judges, and academics across the country began considering how to remedy problems in the system, using the information tendered at the Conference.

\section{2010-Present: Pilot Projects and Implementation}

Today, numerous pilot projects are in various stages of consideration and implementation around the country. In some jurisdictions, task forces have been formed and have offered initial recommendations, as in Minnesota $^{27}$ and Iowa. ${ }^{28}$ In a few states, such as New Hampshire ${ }^{29}$ and

21. Memorandum from Hon. Mark R. Kravitz, Chair, Advisory Comm. on Fed. Rules of Civil Procedure, to Hon. Lee H. Rosenthal, Chair, Standing Comm. on Rules of Practice \& Procedure, Report of the Civil Rules Advisory Committee 7 (May 17, 2010), available at http://www. uscourts.gov/uscourts/RulesAndPolicies/rules/Reports/CV05-2010.pdf.

22. See Inst. For the Advancement of the Am. Legal Sys., Preserving Access AND IDENTIFYING EXCESS: AREAS OF CONVERGENCE AND CONSENSUS IN THE 2010 CONFERENCE MATERIALS 13 (2010), http://uscourts.gov/uscourts/RulesAndPolicies/rules/Duke\%20Materials/Lib rary/IAALS,\%20Preserving\%20Access\%20and\%20Identifying\%20Excess.pdf.

23. Id. at 1.

24. See Memorandum from Hon. David G. Campbell, Chair, Standing Comm. on Rules of Practice \& Procedure, to Hon. Mark R. Kravitz, Chair, Advisory Comm. on Fed. Rules of Civil Procedure, Report of the Civil Rules Advisory Committee 2-6 (Dec. 2, 2011), available at http://www.uscourts.gov/uscourts/RulesAndPolicies/rules/Reports/CV12-2011.pdf.

25. Id. at 7.

26. See Civil Rules Advisory Comm., Draft Minutes 13-19 (Nov. 2, 2012), available at http://www.uscourts.gov/uscourts/RulesAndPolicies/rules/Minutes/CV11-2012-min.pdf.

27. Civil Justice Task ForCe, Recommendations of the Minnesota Supreme Court Civil JUSTICE REFORM TASK FORCE: FinAL REPORT (2011), http://www.mnbar.org/sections/out state-practice/Final\%20civil\%20reform\%20task\%20force\%20report.pdf.

28. IOWA Civil Justice Reform TASK ForCE, Reforming the IOWA Civil Justice System (2012), http://www.iowacourtsonline.org/wfdata/files/Committees/CivilJusticeReform/FINAL03_22 
Massachusetts, ${ }^{30}$ the pilot projects have run their course and evaluationand even broader implementation-is underway. Additional projects are in process in Colorado ${ }^{31}$ and Utah, $^{32}$ and in federal courts in Pennsylvania, ${ }^{33}$ New York, ${ }^{34}$ and the Seventh Circuit. ${ }^{35}$

While there are common themes among these efforts, each project is unique in its proposed solutions and design. For example, Utah has implemented broad-sweeping, permanent statewide rule changes that mandate proportionality through tiers of discovery based on the amount in controversy. ${ }^{36}$ The Colorado Supreme Court is experimenting with Civil Access Pilot Project (CAPP) rule changes in business cases in select judicial districts for a period of two years, whereupon the pilot project will be evaluated. ${ }^{37}$ The rule changes in both states are based on the ACTL's proposed Principles, with the goal of narrowing and framing the issues to achieve proportional and targeted discovery.

_12.pdf.

29. See Order Adopting Superior Court PAD Pilot Rules (N.H. Apr. 6, 2010), available at http://www.courts.state.nh.us/supreme/orders/04-06-2010-Order-adopting-PAD-Pilot-ProjectRules.pdf (adopting Superior Court PAD pilot rules relating to proportional discovery and automatic disclosure for Carroll and Strafford County Superior Courts). For more information on the New Hampshire project, see Superior Court-Civil Rules Pilot Project: "Proportional Discovery/Automatic Disclosure” (PAD), N.H. JUD. BRANCH, http://www.courts.state.nh.us/superior /civilrulespp/index.htm (last visited Feb. 16, 2013).

30. See Bus. Litig. Session, Mass. Superior Court, BLS Pilot Project, http://www.mass. gov/courts/press/superior-bls-pilot-project.pdf [hereinafter BLS PILOT PROJECT] (announcing that parties may participate in a voluntary pilot project designed to reduce discovery costs).

31. See Colorado Civil Rules Pilot Project, Jud. BRANCH ST. OF Colo., http://www.courts. state.co.us/Courts/Civil_Rules.cfm (last visited Feb. 16, 2013).

32. See Utah Rules of Civil Procedure, UTAH ST. CTS. http://www.utcourts.gov/resources/ rules/urcp/ (last visited Feb. 16, 2013) (showing numerous amendments to rules governing discovery). Utah is included here because of the broad, sweeping changes that have been implemented. These changes are not technically a "pilot program" because they have been implemented permanently rather than on an experimental basis.

33. See Electronic Discovery Special Masters, U.S. District CT. W. District PA., http://www.pawd.uscourts.gov/Pages/ediscovorey.htm (last visited Feb. 16, 2013) (reporting that special masters are available to assist on electronic discovery issues).

34. See Judicial Improvements Comm. of the S. Dist. Of N.Y., Pilot Project Regarding Case Management Techniques fOR Complex Civil CaSes (2011), http://www.nysd.uscourts .gov/rules/Complex_Civil_Rules_Pilot.pdf [hereinafter S.D.N.Y. PILOT PROJECT].

35. See Statement of Purpose and Preparation of Principles, Discovery Pilot: SEVENTH Circuit Electronic Discovery Pilot Program, www.discoverypilot.com (last visited Feb. 16, 2013).

36. See Utah R. Civ. P. 26.

37. See Chief Justice Directive 11-02: Adopting Pilot Rules for Certain District Court Civil Cases (Colo. Oct. 7, 2011), available at http://www.courts.state.co.us/Courts/Supreme_Court /Directives/CJD\%2011-02amendedappendixes12-12-11.pdf [hereinafter Chief Justice Directive 1102]. 
Various entities - including the National Center for State Courts, the Federal Judicial Center, and IAALS - have responsibility for evaluating the projects. For example, in Colorado, IAALS is studying the state's pilot project at the request of the Colorado Supreme Court. IAALS is also serving as the clearinghouse for all of these projects by maintaining and publishing on its website current knowledge regarding all pilot projects around the country. ${ }^{38}$ It is IAALS's hope that every project will be evaluated to some degree, so that data can be broadly shared and digested. Further, while varying projects around the country are a necessary outgrowth during this period of experimentation, a future goal is to return to more uniform rules that have demonstrated potential of better serving the goals of a just, speedy, and inexpensive process for civil litigation. While a few projects have begun to produce data, with positive survey results in both the Seventh Circuit $^{39}$ and in Massachusetts, ${ }^{40}$ most of the pilot projects now underway will begin producing meaningful data in late 2013 or early 2014.

\section{Common Themes Among StATE AND Federal Pilot Projects}

While it is too soon to draw conclusions from the pilot projects since they are ongoing and final data has yet to be collected and analyzed, we can look at the pilot projects themselves to draw common themes from their design and purpose. Thus, while we are in a holding pattern as to what works and what does not, we can look to the projects and define common themes of experimentation. At a minimum, we can know what the attorneys, judges, academics, and court professionals who designed the projects intended them to achieve. Looking across the state and federal pilot projects, several themes emerge: (1) case differentiation, or experimentation with different sets of rules for different sorts of cases (moving from "transsubstantive rules" to an acceptance of the "one size

38. See Rule One Initiative: Implementation, IAALS, http://iaals.du.edu/initiatives/rule-oneinitiative/implementation (last visited Feb. 16, 2013).

39. Seventh Circuit Electronic Discovery Pilot Program, Final Report on Phase TwO: MAY 2010-MAY 2012, at 4-5 (2012), http://www.discoverypilot.com/sites/default/files/PhaseTwo-Final-Report-Appendix.pdf (reporting that the Principles are perceived to result in more cooperation, greater access to needed information, and increased fairness).

40. Massachusetts Superior Court Business Litigation Session Pilot Project PRELIMINARY SURVEY Findings (Sept. 2012) (on file with authors) (“A significant majority of respondents concluded that the pilot was 'much better' or 'somewhat better' than other BLS cases with respect to ... timeliness and cost-effectiveness of discovery, the timeliness of case events, access to a judge to resolve discovery issues, absence of unnecessary burdens in producing discovery, and cost-effectiveness of case resolution.”). 
does not fit all” principle); (2) express incorporation of proportionality principles in discovery; and (3) procedures that increase judicial case management. These themes are consistent with the proposed Principles originally set out by the ACTL Task Force, the needs identified by the various empirical studies, and the themes that arose from the Duke Conference in 2010.

\section{A. Using Case Differentiation to Solve Issues of Cost and Delay}

The current approach in the federal system, and most state systems, is a "one size fits all" approach where a single set of uniform rules governs most cases in the general jurisdiction court. While there are many benefits to a uniform set of rules that applies across jurisdictions, such uniformity does not require lockstep procedures that treat all cases in the same manner within a jurisdiction. The Task Force thus proposed that "rulemakers should have the flexibility to create different sets of rules for certain types of cases so that they can be resolved more expeditiously and efficiently." ${ }^{41}$ IAALS found that state and federal judges agreed in their 2010 survey, with 70\% of trial judge respondents agreeing, that the "civil justice system works well for certain types of cases but not others." ${ }^{2}$ For that reason, respondents supported different treatment for certain cases, particularly more complex cases. $^{43}$ Consistent with this theme, several of the pilot projects attempt to define rules by case type or based on case complexity.

One such pilot project at the federal level is the Initial Discovery Protocols for Employment Cases Alleging Adverse Action. ${ }^{44}$ The protocols were presented to the Civil Rules Advisory Committee in November 2011 and approved for implementation across the nation by judges on a voluntary basis. The protocols "create a new category of information exchange, replacing initial disclosures with initial discovery" specific to these types of cases and automatically provided. ${ }^{45}$ While further discovery is not affected, the intent of the protocols is to assure that the early and automatic exchange of information will focus and

41. See FinAL REPORT, supra note 4, at 4.

42. Gerety, supra note 13 , at 303.

43. See id.

44. See Fed. Judicial Ctr., Pilot Project Regarding Initial Discovery Protocols For EMPLOYMENT CASES ALLEGING ADVERSE ACTION 2 (2011), http://www.fjc.gov/public/pdf.nsf /lookup/DiscEmpl.pdf/\$file/DiscEmpl.pdf.

45. Id. 
streamline the dispute - to the benefit of both the plaintiff and the defendant. The Federal Circuit's Advisory Council similarly designed a Model Order on E-Discovery in Patent Cases, which is intended to provide a starting point for targeted and streamlined electronic discovery in patent cases. ${ }^{46}$ In Colorado, the CAPP program focuses on business litigation. ${ }^{47}$ The goal of CAPP is to streamline the civil litigation process through new pleading and disclosure procedures that require early information exchange, as well as proportionate discovery. The Massachusetts Business Litigation Session (BLS) likewise piloted a project in 2010 and 2011 that applied to business cases on a voluntary basis, with the goal of addressing the increasing burden and costs of civil pretrial discovery—particularly electronic discovery. ${ }^{48}$

In some jurisdictions, the pilot projects focus on the most complex cases, irrespective of subject matter, to address the issues of cost and delay in those cases that are often the worst offenders. The Southern District of New York's Pilot Project Regarding Case Management Techniques for Complex Civil Cases took effect on November 1, 2011, and focuses on increased and more targeted judicial case management to address concerns of cost and delay in complex cases. ${ }^{49}$ That pilot project is a "response to the federal bar's concerns about the high cost of litigating complex civil cases," with the goal being to "improve judicial case management of these disputes and reduce costs and delay." Ohio's Supreme Court Task Force on Commercial Dockets also has experimented with a pilot commercial docket, and now recommends the permanent establishment of commercial dockets. ${ }^{51}$ Such an approach is consistent with IAALS's study of the processes in Oregon, where the rules provide for a relatively automated process and rapid trial settings in

46. See Advisory Council for the U.S. Court of Appeals For the Fed. Circuit, AN EDISCOVERY MODEL ORDER 2, available at http://www.cafc.uscourts.gov/2011/model-e-discoveryorder-adopted-by-the-federal-circuit-advisory-counsel.html (last visited Apr. 24, 2013).

47. Chief Justice Directive 11-02, supra note 37, app. A ("Pilot project business actions are not limited to 'business v. business,' but also include 'business v. individual' and 'individual v. individual' business cases.”).

48. Introduction to BLS PILOT PROJECT, supra note 30.

49. S.D.N.Y. PILOt Project, supra note 34, at ii.

50. Press Release, Office of the District Court Executive, S.D.N.Y. Implements Innovative Pilot Program to Improve the Quality of Judicial Case Management in Complex Civil Cases (Nov. 4, 2011), available at http://www.nysd.uscourts.gov/file/news/complex_civil_case_pilot.

51. Supreme COURT OF OHIO, REPORT AND RECOMMENDATIONS OF THE SUPREME COURT OF OHIO TASK FORCE ON COMMERCIAL DOCKETS 5 (2011), http://www.supremecourt.ohio.gov/Boards /commDockets/Report.pdf. 
all civil cases, except when a case is designated as "complex," whereupon different procedures apply. ${ }^{52}$

On the other end of the spectrum, innovative projects have sprung up around the country dealing with the simplest of cases. These programs offer short, summary, and expedited processes for simple cases so that parties can gain access to the system, and a jury or bench trial, in a way that is affordable and proportional. ${ }^{53}$ These programs, which are often marked both by an expedited pretrial process and an expedited trial process, are growing in popularity around the country. Although designed and primarily used for smaller-dollar-value cases, because these programs offer the advantages of a fixed and early trial with streamlined discovery, attorneys have recognized the benefits of such procedures in larger cases as well. Expedited trial programs have been established, or are under development, in Arizona, ${ }^{54}$ California state $^{55}$ and federal ${ }^{56}$ court, the Western District of Washington, ${ }^{57}$ Oregon, ${ }^{58}$ Texas, ${ }^{59}$ Nevada, ${ }^{60}$ Utah $^{61}$ the Western District of Pennsylvania, ${ }^{62}$ South Carolina, ${ }^{63}$ and New York. ${ }^{64}$ While simple cases are not the worst

52. See InSt. FOR THE ADVANCEMENT OF THE AM. LEGAL SYs., supra note 17, at 2 (discussing Oregon's limits on discovery and requirement that civil cases be tried within one year).

53. See Paula L. Hannaford-Agor et Al., NAT'L Ctr. For State Courts, Short, SUMMARY \& EXPEDITED: THE EVOLUTION OF CIVIL JURY TRIALS 6-7 (2012), http://www.ncsc. org/ /media/Fiks/PDF/Information\%20and\%20Resources/Civil\%20cover\%20sheets/ShortSummary Expedited-online\%20rev.ashx (describing expedited procedures in six jurisdictions); INST. FOR THE AdVANCEMENT Of THE AM. LEGAL Sys. ET AL., A RETURN TO TRIALS: IMPLEMENTING EFFECTIVE Short, Summary, And ExPedited Civil ACTION PROGRAMS 3-4 (2012), http://iaals.du.edu/ images/wygwam/documents/publications/A_Return_to_Trials_Implementing_Effective_Short_Su mmary_and_Expedited_Civil_Action_Programs.pdf (discussing common characteristics of programs in various jurisdictions designed to provide litigants with speedy and less expensive access to civil trials).

54. See HANNAFORD-AGOR ET AL., supra note 53, at 22-28.

55. Expedited Jury Trials, CAL. CTS., http://www.courts.ca.gov/12774.htm (last visited Feb. 17, 2013)

56. Gen. Order No. 64: Expedited Trial Procedure (N.D. Cal. June 21, 2011), available at http://www.cand.uscourts.gov/generalorders.

57. LOCAL RULES W.D. WASH. LCR 39.2.

58. Chief Justice Order No. 10-025, Order of Out-of-Cycle Adoption of New UTCR 5.150, UTCR Form 5.150.1a, and UTCR Form 5.150.1b (Or. May 6, 2010), available at http://courts. oregon.gov/OJD/docs/programs/utcr/CJO_10-025.pdf (adopting a rule allowing for expedited civil jury cases).

59. Order Adopting Rules for Dismissals and Expedited Actions, No. 12-9191, at 4-5 (Tex. Nov. 13, 2012), available at http://www.supreme.courts.state.tx.us/miscdocket/12/12919100.pdf.

60. NeV. ShORT TRIAL R. 1-35.

61. UTAH CODE ANN. §§ 78B-3-901 to -909 (West Supp. 2012).

62. U.S. Dist. COURT FOR ThE W. Dist. OF PA., Pilot Program FOR EXPEdited CiviL LITIGATION, http://www.pawd.uscourts.gov/Documents/Forms/EXPEDITED_DOCKET.pdf.

63. See HANNAFORD-AGOR ET AL., supra note 53, at 8-17. 
offenders with regard to the judiciary's time and resources, there is more concern that they are the ones being priced out of the system. Programs that address the needs of these smaller-dollar-value cases help provide access to the courts by offering a proportionally simpler and more expedited process.

\section{B. Achieving Proportionality in Discovery}

Proportionality in discovery tends to be a principle that pervades all of the pilot projects, even if the focus of a particular project is in another area; but proportionality is also a stand-alone theme. One of the proposed Principles from the Final Report is that "[p]roportionality should be the most important principle applied to all discovery." need for proportionality resonates throughout the survey responses from judges, attorneys, and general counsel. Pilot projects around the country have taken up this cause, and many are experimenting with rule reforms, with the primary goal of achieving proportionality in discovery.

Based on the empirical research to date, these changes are needed. As part of its survey of state and federal judges, IAALS found that "[o]ver 90 percent of state judges and over 75 percent of federal judges reported that they impose additional limits on the number of depositions 'almost never' or only 'on occasion.",66 Over half the federal judges responded that they "almost never" invoke the proportionality provision in Federal Rule of Civil Procedure 26(b)(2)(C) of their own accord to limit discovery. ${ }^{67}$ From the general counsel perspective, respondents of IAALS's survey found that "litigation costs are commonly out of line with the stakes of the case," with nine out of ten respondents disagreeing that "litigation costs are generally proportionate to the value of the case." "68

Several reform efforts seek to ensure proportionality by flipping the discovery paradigm from an "all facts are discoverable unless the court decides otherwise" framework to one that expressly limits the scope of discovery unless the court decides otherwise. This concept is otherwise stated as requiring the judges to "manage up" rather than "manage

64. See id. at 29-37.

65. FINAL REPORT, supra note 4, at 7.

66. Gerety, supra note 13 , at 304 .

67. Id.

68. INST. FOR THE ADVANCEMENT OF THE AM. LEGAL Sys., supra note 14, at 1 (internal quotation marks omitted). 
down" in controlling the process of the case. ${ }^{69}$ The Massachusetts BLS Pilot Project rules provide that "[t]he court, with the parties, will determine the scope and timing of permitted discovery, generally at the initial Rule 16 Case Management conference. The concept of limited discovery proportionally tied to the magnitude of the claims actually at issue will be the guiding principle." ${ }^{, 70}$ The rules also provide that "[d]iscovery in general and document discovery in particular will be limited to documents and information that would enable a party to prove or disprove a claim or defense, or enable a party to impeach a witness."71 Beyond the discovery outlined, the rules provide for "no additional discovery absent agreement or a court order, which will be made only after a showing of good cause and proportionality."72 Colorado's CAPP program has a similar discovery scheme, intended to ensure limited and proportional discovery. ${ }^{73}$

Utah has taken a different tack, with sweeping changes to discovery rules implemented in 2011 to address the expansion and increased cost of discovery. ${ }^{74}$ The rules require automatic initial disclosures, ${ }^{75}$ and the scope of discovery is expressly limited by the standard of proportionality, ${ }^{76}$ which is defined in the rules. ${ }^{77}$ Parties "seeking discovery always [have] the burden of showing proportionality and relevance."78 Discovery is further limited by tiers based on the amount in controversy. ${ }^{79}$

69. See Steven S. Gensler, Judicial Case Management: Caught in the Crossfire, 60 DUKE L.J. 669, 739 (2010) (discussing how judges "manage up" in big cases when the rules are written for small cases and "manage down" in small cases when the rules are written for big cases (internal quotation marks omitted)).

70. BLS PILOT PROJECT, supra note 30, princ. A.

71. Id. princ. D.

72. Id. princ. G.

73. See Chief Justice Directive 11-12, supra note 37, Pilot Project Rules 1.3, 9.1, 9.2. Rule 1.3 provides the guiding principle of proportionality, which "shall shape the process of the case in order to achieve a just, timely, efficient and cost effective determination of all actions.” Rule 9.2 provides that discovery is "limited in accordance with the initial case management order" and that "[n]o other discovery will be permitted absent further court order based on a showing of good cause and proportionality."

74. See Notice from Utah Supreme Court Advisory Committee, UTAн ST. CTS. (June 21, 2011), http://www.utcourts.gov/resources/rules/comments/20110621/ (including rules with and without redline for comparison).

75. See UtAH R. Civ. P. 26(a)(1).

76. Id. 26(b)(1).

77. See id. $26(\mathrm{~b})(2)$

78. Id. 26(b)(3).

79. See id. 26(c)(3). Discovery is limited as follows: (1) actions claiming $\$ 50,000$ or less are limited to three deposition hours, zero interrogatories, five requests for production, five requests for 
In addition to imposing proportionality by redefining the scope of discovery, jurisdictions are also working to achieve proportionality through increased cooperation among attorneys. ${ }^{80}$ The Seventh Circuit Electronic Discovery Pilot Project is a good example. Principle 1.02 of that Project provides that "[a]n attorney's zealous representation of a client is not compromised by conducting discovery in a cooperative manner. The failure of counsel or the parties to litigation to cooperate in facilitating and reasonably limiting discovery requests and responses raises litigation costs and contributes to the risk of sanctions." ${ }^{81}$ After the court "determines that any counsel or party in a case has failed to cooperate and participate in good faith in the meet and confer process or is impeding the purpose of these Principles, the Court may require additional discussions prior to... discovery, and may impose sanctions.” ${ }^{, 2}$ Other pilot projects seek to increase levels of cooperation by requiring early and frequent conferencing. The Massachusetts BLS Pilot Project specifically requires that parties "confer early and often about discovery and, especially in complex cases, to make periodic reports of th[o]se conferences to the court." 83 Several of the pilot projects require the parties to meet and confer regarding preservation. ${ }^{84}$ Courts are also getting involved to ensure proportionality, as in the Massachusetts BLS project where "periodic litigation control conferences concerning discovery" are required, ${ }^{85}$ and Colorado's CAPP project, where judges determine and set forth a detailed discovery plan in the initial case management order based on proportionality. ${ }^{86}$

admission, and 120 days to complete discovery; (2) actions claiming more than $\$ 50,000$ and less than $\$ 300,000$ or non-monetary relief are limited to fifteen deposition hours, ten interrogatories, ten requests for production, ten requests for admission, and 180 days to complete discovery; and (3) actions claiming more than $\$ 300,000$ are limited to thirty deposition hours, twenty interrogatories, twenty requests for production, twenty requests for admission, and 210 days to complete discovery.

80. See generally The Sedona Conference ${ }^{\circledR}$, The Sedona Conference ${ }^{\circledR}$ Cooperation Proclamation, 10 SEDONA CoNF. J. 331, 331 (2009 Supp.) (promoting "cooperation by all parties to the discovery process" so as to achieve efficient and inexpensive resolutions).

81. Seventh Circuit Electronic Discovery Committee, Principles Relating to the DISCOVERY OF ELECTRONICALLY STORED INFORMATION, princ. 1.02 (2010), www.discoverypilot. com/sites/default/files/Principles8_10.pdf [hereinafter SEvENTH CiRCUIT PRINCIPLES].

82. Id. princ. 2.01(d)

83. See BLS PILOT PROJECT, supra note 30, princ. H (quoting FinAl Report, supra note 4, at 21) (internal quotation marks omitted).

84. See, e.g., Chief Justice Directive 11-12, supra note 37, Pilot Project Rule 6.1; BLS PILOT Project, supra note 30, princ. E; SEVEnTH Circuit PRINCIPLES, supra note 81, princ. 2.04(c).

85. BLS PILOT PROJECT, supra note 30, princ. H (citing FINAL REPORT, supra note 4, at 19).

86. See Chief Justice Directive 11-02, supra note 37, Pilot Project Rule 7.2. 


\section{Achieving Efficiency Through Increased Judicial Case Management}

Beyond case management techniques specifically addressing proportionality, there is a loud cry for active judicial case management throughout the whole process - from the start of litigation to the end of the case- to ensure a more efficient and less costly process. One of the most broadly endorsed themes that arose out of the research and Duke Conference was the need for increased active case management by a single judge. The IAALS/ACTL survey found that "nearly $90 \%$ of Fellows agreed that one judicial officer should handle a case from start to finish." ${ }^{87}$ The respondents of the ABA and NELA studies agreed, with $85 \%$ and $80 \%$ of respondents preferring one judicial officer, respectively. ${ }^{88}$ Likewise, $85 \%$ of state court judges responded that they believe "one judicial officer should handle a case from start to finish." 99 CAPP directly addresses these concerns by assigning cases to a single judge for all purposes through final resolution of the case. ${ }^{90}$

Pilot projects often include provisions regarding pretrial conferences. Multiple pilot projects require in-person initial pretrial conferences with the court to encourage early communication and involvement by the court. $^{91}$ The Southern District of New York's pilot project is specifically focused on judicial case management to achieve a less costly and more efficient process. With regard to discovery disputes not involving the assertion of a privilege or work product, the dispute must be submitted to the court by letter rather than by motion. ${ }^{92}$ For all other motions, with certain exceptions, pre-motion conferences with the court are required and are held upon request by letter. ${ }^{93}$ Thus, the pilot projects recognize the importance of, and incorporate: active judicial case management from the beginning of the case; the need for judges to factor in proportionality early in the process; encouraging communication between counsel and with the court prior to motions; limiting written motions; and productive pre-motion, pre-discovery, and pre-trial conferences.

87. IAALS/ACTL TASK FORCE SURVEY, supra note 2, at A-6.

88. ABA SECTION OF LITIGATION, supra note 10, at 11; HAMBURG \& KosKI, supra note 11, at

8.

89. Gerety, supra note 13, at 302.

90. Chief Justice Directive 11-02, supra note 37, Pilot Project Rule 5.1.

91. See, e.g., id. Pilot Project Rule 7.1; S.D.N.Y. PILOT ProJeCt, supra note 34, § I.B.

92. S.D.N.Y. PILOT PROJECT, supra note 34, § II.B.

93. Id. § III.A. 


\section{CONCLUSION}

In short, from 2007 to today, we have witnessed the beginnings of a sea change in the way that attorneys and judges approach the civil justice system. The conversation no longer focuses on whether there is a problem - but rather how to fix it. While good judges and attorneys will incorporate improvements in their practice without formal rule changes, there is recognition that changes in the rules are necessary, but not necessarily sufficient, to institutionalize true change in the way cases are handled, both by attorneys and judges. Jurisdictions are experimenting with rule changes that treat cases differently based on case type, size, or complexity. With the goal of identifying the particular needs of the cases, and assigning them to processes and procedures best designed to address their needs, the hope is that such case differentiation will limit the costs and delays for all cases.

Particularly due to the advent of electronic discovery, and the vast increase in the overall volume of potentially discoverable information, pilot projects have adopted proportionality as a guiding star throughout the case so that litigation remains just, speedy, and inexpensive. Because the rules govern the procedures and proceedings in each case, the rules must be amended to incorporate this concept to achieve real change, and pilot projects throughout the country are blazing the way. The pilot projects are also a proving ground for the notion of cooperation among and between the parties. Attorneys who have put aside gamesmanship and embraced the concept of cooperation report that it has not undermined the zealous representation of their clients. ${ }^{94}$ In fact, it is becoming an essential component of appropriate representationparticularly in the area of electronic discovery-in order to achieve a just, speedy, and inexpensive determination for clients.

Judicial caseflow management has been recognized as another essential element in moving a case fairly, efficiently, and economically through the process. Early judicial involvement in every case, by a single judge assigned to the case from start to finish, is more efficient. Additionally, firm trial dates, enforced timelines, streamlined motions practice, and judicial availability are other tools that are being used to move the process along and reduce the time and cost burden on litigants.

94. See, e.g., Seventh Circuit Electronic Discovery Pilot Program, supra note 39, at 4 (reporting that $96 \%$ of attorneys surveyed as part of the pilot program reported either no effect or an increase in ability to represent zealously). 
These three elements quite often exist together in the pilot projects, and as a threesome, may presage the wave of the future. Rules set the expectations and can change the legal culture; but a good judge also plays a critical role in early case management and enforcement of those expectations, and attorneys must cooperate to achieve the intended outcomes. And, for any of those changes to occur in an institutionalized way, there must be leadership from the bench and the bar. We are past talking about whether there is a problem, and are now experimenting with solutions, and we must stand on the shoulders of the successes and failures of projects now underway in order to reach for our ultimate objective: a just, speedy, and inexpensive determination of every action. 